\title{
PLURILINGVIZAM I OBRAZOVNA JEZIČKA POLITIKA EVROPSKE UNIJE U SRBIJI
}

\begin{abstract}
Katarina RADOJKOVIĆ ILIĆ*
Apstrakt: U radu se razmatra plurilingvizam kao okosnica evropske jezičke ideologije, kao i koncept plurilingvalnog i interkulturnog obrazovanja čiji je osnovni cilj promovisanje humanističkih vrednosti, međusobnog poštovanja, otvorenosti, tolerancije i dijaloga među narodima. Navode se neki od akata institucija Evropske unije i Saveta Evrope u kojima se plurilingvizam i očuvanje jezičke raznovrsnosti ističu kao najznačajniji ciljevi evropske obrazovne jezičke politike. Takođe se razmatraju neka od spornih pitanja vezanih za jezičko obrazovanje u zemljama Evropske unije i analizira koliko je plurilingvizam zastupljen u obrazovnoj jezičkoj politici u Republici Srbiji. Navode se i rezultati istraživanja sprovedenog sa studentima Pravnog fakulteta Univerziteta u Beogradu u kome su ispitivana njihova iskustva i stavovi prema učenju stranih jezika uopšte, a posebno prema značaju poznavanja više jezika za njihovu buduću profesionalnu karijeru i pristup programima mobilnosti.

Ključne reči: Evropska obrazovna jezička politika, Evropska unija, pluriligvizam, nastava stranog jezika, Savet Evrope.
\end{abstract}

\section{1) UVOD}

Evropska jezička politika usmerena je ka razvoju plurilingvizma još od samog osnivanja Evropskih zajednica. Uredbom br. 1 o određivanju jezika koji se koriste u Evropskoj ekonomskoj zajednici utvrđeno je još 1958. godine da će četiri zvanična jezika, koje priznaju šest država osnivača (Italija, Francuska, Nemačka, Belgija, Holandija i Luksemburg), biti italijanski, francuski, nemački i holandski. ${ }^{1}$ Kako se

\footnotetext{
* Pravni fakultet u Beogradu, e-mail: katarina.radojkovic@ius.bg.ac.rs.

Rad je nastao u okviru projekta Identitetski preobražaj Srbije 2020, čiji je nosilac Pravni fakultet Univerziteta u Beogradu.

1 "Regulation no 1 determining the languages to be used by the European Economic Community", Official Journal 017, 06/10/1958, pp. 0385-0386.
} 
tokom godina broj država članica Evropske unije povećavao, rastao je i broj jezika, da bi danas broj zvaničnih jezika Evropske unije dostigao dvadeset četiri a broj manjinskih i regionalnih jezika premašio šezdeset. U mnogobrojnim aktima institucija Evropske unije i Saveta Evrope ističe se da su plurilingvizam i jezička raznovrsnost najznačajniji ciljevi jezičke obrazovne politike Evropske unije i da obrazovanje ima za osnovni cilj promovisanje humanističkih vrednosti, međusobnog poštovanja, otvorenosti, tolerancije i dijaloga među narodima. Ovde ćemo navesti samo nekoliko najznačajnijih dokumenata, kao što je Preporuka R (82) 18 Komiteta Ministara Saveta Evrope ${ }^{2}$ u kojoj se traži da se u školama obezbedi učenje bar jednog evropskog ili regionalnog jezika, pored maternjeg, počev od uzrasta od 10 godina a po mogućstvu i ranije, i insistira na razvoju jezičke raznovrsnosti tako da se, kad god je moguće, učenicima pruži mogućnost da uče više evropskih ili drugih jezika i promovišu međunarodni kontakti sa učenicima drugih zemalja i studijska putovanja u inostranstvo. Takođe se ističe da lingvistička i kulturna raznovrsnost Evrope predstavlja dragocenu zajedničku baštinu, i da obrazovanje treba usmeravati ka razvoju pozitivnih stavova prema različitostima kako one ne bi činile prepreku za komunikaciju, već bi bile izvor bogatstva i međusobnog razumevanja.

Ključni dokument za zaštitu regionalnih i manjinskih jezika je Evropska povelja o regionalnim ili manjinskim jezicima koju je 24. juna 1992. godine usvojio Savet Evrope. ${ }^{3}$ Ona se odnosi na jezike koje govori manjinski deo populacije, bilo da su u pitanju regionalni jezici, odnosno jezici koji se govore u okviru iste države a čije je kulturno poreklo različito od kulture te države (na primer korzikanski na Korzici, bretonski u Bretanji, ili flamanski u Flandriji) ili manjinski jezici, odnosno jezici koje govori veliki broj pripadnika etničke manjine u jednoj državi (kao što je nemačka manjina u Danskoj). Države potpisnice ove Povelje obavezuju se da će priznavati regionalne i manjinske jezike kao izraz kulturnog bogatstva, odlučno promovisati njihovu upotrebu u javnom i privatnom životu i preduzimati mere za sprečavanje svakog oblika diskriminacije, ugrožavanja, isključivanja, ograničavanja ili nepovoljnog tretmana regionalnog ili manjinskog jezika, koji bi imao za cilj da obeshrabri ili dovede u pitanje njegovo održavanje i razvoj. Članom 8 propisuju se posebne mere koje se odnose na uvođenje regionalnih i manjinskih jezika u predškolsko, osnovno i srednjoškolsko obrazovanje, tehničko, specijalističko, univerzitetsko i drugo visokoškolsko obrazovanje i stvaranje mogućnosti za studiranje ovih jezika kao predmeta na univerzitetima.

\footnotetext{
2 "Recommandation $\mathrm{N}^{\circ} \mathrm{R}(82) 18$ du Comité des ministres aux états membres concernant les langues vivantes", Conseil de l'Europe, Strasbourg, 1982.

3 “Charte européenne des langues régionales ou minoritaires", Conseil de l’Europe, Strasbourg, 1992.
} 
U Rezoluciji Saveta Evropske unije o poboljšanju i diversifikaciji nastave jezika traži se da u okviru školovanja svaki učenik može, pored maternjeg, da uči najmanje dva jezika Evropske unije. ${ }^{4}$ Slični zahtevi izneti su u Rezoluciji Saveta Evropske unije od 16. decembra 1997. u kojoj se insistira na ranom učenju stranih jezika. ${ }^{5}$

U Beloj knjizi Evropske komisije o obrazovanju iz 1995. godine proklamuje se pet ciljeva obrazovne jezičke politike EU, od kojih je jedan da svaki evropski građanin treba da zna tri evropska jezika. ${ }^{6} \mathrm{U}$ dokumentu se navodi da je ostvarenje ovog cilja neophodno da bi evropski građani mogli da iskoriste mogućnosti koje im pruža zajedničko tržište, da se prilagode drugačijem radnom i kulturnom okruženju i da razviju osećaj pripadnosti Evropi u njenom kulturnom bogatstvu i raznolikosti. U Preporuci R (98) 6 ističe se da učenje jezika u cilju razvoja plurilingvizma predstavlja evropski politički interes, i da se potrebe multilingvalne i multikulturne Evrope mogu zadovoljiti samo značajnim unapređenjem mogućnosti njenih građana da prevaziđu jezička i kulturna ograničenja, a da takav cilj podrazumeva postojanje dobro organizovanog sistema obrazovanja tokom celog života finansiranog od strane odgovarajućih institucija. ${ }^{7}$ Takođe se ukazuje na opasnost od marginalizacije lica koja ne poseduju potrebne sposobnosti da komuniricaju u interaktivnoj Evropi. Stoga se mere koje se preporučuju u ovom dokumentu odnose, pre svega, na razvoj obrazovnih politika kojima bi se omogućilo svim Evropljanima da se osposobe da komuniciraju sa govornicima drugih jezika, s ciljem da razvijaju otvorenost duha, da se poboljša slobodno kretanje ljudi i razmena informacija koje bi omogućile učenicima da nauče da poštuju način života drugih i žive u interkulturnom svetu.

Kada je reč o očuvanju jezičke raznovrsnosti neophodno je spomenuti još i Preporuku Parlamentarne skupštine Saveta Evrope R 1383 iz 1998. godine. ${ }^{8}$ U ovom aktu Skupština predlaže Savetu Ministara da definiše jezičku raznovrsnost kao prioritet jezičke obrazovne politike. U dokumentu se navodi da prema statističkim podacima velika većina učenika u Evropi uči engleski, dok „veliki“ evropski jezici - nemački, francuski, španski i italijanski zaostaju, a jezici kao

\footnotetext{
4 "Council Resolution of 31 March 1995 on improving and diversifying language learning and teaching within the education systems of the European Union", Official Journal C 207, 12/08/1995, pp. 0001-0005.

5 "Council Resolution of 16 December 1997 on the early teaching of European Union languages", Official Journal C 1, 03/01/1998.

6 "Livre blanc sur l'éducation et la formation. Enseigner et apprendre. Vers la société cognitive", Commission Européenne (CE), COM (95) 590, 1995, p. 54.

7 "Recommandation $N^{\circ} \mathrm{R}(98) 6$ du Comité des ministres aux Etats membres concernant les langues vivantes", Conseil de l'Europe, Strasbourg, 1998.

8 "Recommandation 1383 (1998) - diversification linguistique", Conseil de l'Europe, Assemblée Parlementaire, Strasbourg, 1998.
} 
portugalski, arapski ili ruski koje govore stotine hiljada ljudi u svetu zauzimaju minorno mesto. Iako se ne osporava značaj engleskog kao lingua franca, konstatuje se da poznavanje samo ovog jezika nije dovoljno da bi Evropa opstala u međunarodnoj ekonomskoj konkurenciji kao ni da bi sačuvala kulturnu raznovrsnost. Predlaže se nekoliko konkretnih mera kao što je učenje dva strana jezika u toku osnovnog i srednjeg obrazovanja, učenje jezika tokom celog života i uvođenje jezika lokalnih manjina u škole. Takođe se ističe značaj redovnog vršenja anketa i u cilju utvrđivanja stepena jezičke raznovrsnosti u evropskim zemljama. Podaci o jezičkoj raznovrsnosti dobijeni putem ovih istraživanja koristili bi se za formiranje obrazovne jezičke politike u tim zemljama.

\section{2) KONCEPT M+2 U TEORIJI I PRAKSI}

Šezdeset godina kasnije, obrazovna jezička politika EU i dalje je usmerena ka plurilingvalnom obrazovanju i očuvanju jezičke raznovrsnosti. Koncept $\mathrm{M}+2$, prema kome svaki evropski građanin treba da govori pored maternjeg još dva od zvaničnih jezika EU, formirao se postepeno od početka XXI veka. Nakon usvajanja Zaključaka Evropskog saveta u Lisabonu od 23. i 24. marta 2000, kojima se poznavanje stranih jezika učvršćuje u osnovne kompetencije pored poznavanja računara, Evropska komisija i Savet Evropske unije definisali su tri zajednička cilja koji treba da predstavljaju okosnicu obrazovnih politika u kontekstu Evropske unije u sledećih deset godina i načine na koji obrazovni sistemi treba da doprinesu ostvarenju strateških ciljeva definisanih na Savetu u Lisabonu. U izveštaju Saveta za obrazovanje Savetu Evropske unije od 14.02.2001. navodi se da su tri osnovna cilja poboljšanje kvaliteta obrazovnih sistema, kao sredstva socijalne i kulturne kohezije, stvaranje uslova u kojima svako ima pristup obrazovanju i stručnom usavršavanju i otvaranje obrazovnih institucija prema svetu. ${ }^{9} \mathrm{U}$ okviru trećeg cilja ističe se značaj stvaranja evropskog obrazovnog prostora putem unapređenja učenja stranih jezika i povećanja mobilnosti. Stoga se ističe da je neophodno stvoriti uslove za učenje dva jezika Evropske unije, pored maternjeg jezika i to u neprekidnom periodu od najmanje dve godine. Zaključci Evropskog saveta u Lisabonu koji se odnose na učenje stranih jezika potvrđeni su i na Evropskom savetu u Barseloni marta 2002. godine. Pored toga, šefovi država složili su se da podaci o realnim jezičkim kompetencijama stanovnika Evrope nisu dostupni i založili se za uvođenje evropskog indikatora jezičkih kompetencija kako bi se ostvario uvid u realne jezičke kompetencije njenih građana. Ovu inicijativu Evropski Parlament je odobrio 2006. godine.

\footnotetext{
9 “Rapport du Conseil 'Éducation' au Conseil européen sur les objectifs concrets futurs des systèmes d'éducation et de formation", du 14 février 2001, https://eur-lex.europa.eu/legal content/FR/TXT/HTML/?uri=LEGISSUM:c11049\&from=EL (pristupljeno 15.9.2020).
} 
Prema Smernicama za razvoj obrazovnih jezičkih politika u Evropi iz 2007. godine, prevashodni cilj plurilingvalnog obrazovanja je prilagođavanje nastave jezika potrebama evropskih društava i težnjama njenih govornika. ${ }^{10}$ To se može postići na dva načina: diversifikacijom nastave postojećih jezika i traganjem za koherentnošću njenih komponenti, koje se često identifikuju kao različiti nastavni predmeti. Plurilingvalno i interkulturno obrazovanje zamišljeno je kao globalno jezičko obrazovanje koje je transverzalno u odnosu na sve jezike koji se izučavaju u školi, kao i u odnosu na sve nastavne predmete. Cilj ovako osmišljenog obrazovanja je formiranje pojedinaca koji su otvoreni ka pluralnom poimanju sveta i jezičkoj i kulturnoj raznolikosti. Svi nastavni predmeti treba da doprinose takvom obrazovanju i kreiranju identiteta, najpre sadržajem predmeta a potom i primenom odgovarajućeg metodološkog pristupa. U okviru plurilingvalnog i interkulturnog obrazovanja akcenat je na razvijanju plurilingvalne i interkulturne kompetencije koje se definišu na sledeći način: pod plurilingvalnom kompetencijom podrazumeva se sposobnost pojedinca da sukcesivno stiče i koristi različite kompetencije na više jezika na različitim nivoima i sa različitom namenom. ${ }^{11}$ Interkulturna kompetencija obuhvata skup znanja, veština i stavova koji omogućuju pojedincu da na različitim nivoima prepoznaje, razume, interpretira ili prihvati način života i mišljenja koji je drugačiji od onog koji je svojstven njegovoj kulturi. Ova kompetencija predstavlja osnov razumevanja među ljudskim bićima i ne svodi se samo na jezik. ${ }^{12}$ Obe kompetencije su heterogenog i evolutivnog karaktera i razvijaju se tokom celog života u skladu sa iskustvima, ličnim i profesionalnim razvojem svakog pojedinca. Primenom ovako koncipirane jezičke obrazovne politike ne ostvaruje se samo funkcionalna korist poznavanja jezika, već se putem učenja jezika pospešuje zapošljivost (ekonomska korist), podstiče sticanje različitih znanja iz drugih nejezičkih oblasti (kognitivna korist), i kompletno formiranje pojedinca zasnovano na vrednostima koje jezici mogu da pruže (edukativna korist). Takođe, kroz učenje više jezika u školi pospešuju se mogućnosti i sredstva za izražavanje ličnosti (ekspresivna korist), upoznavanje sa delima kulture i umetnosti na nekim od jezika koje se uče u školi (kulturna i interkulturna korist) i, konačno, pospešuje razmišljanje o jeziku u svim njegovim dimenzijama - kao sistemu, sredstvu komunikacije i različitim diskursima (metalingvistička, metakomunikativna, metadiskurzivna i mekakognitivna korist). ${ }^{13}$

\footnotetext{
${ }^{10}$ Jean-Claude Beacco, Michel Byram, De la diversité linguistique à l'éducation plurilingue - Guide pour l'élaboration des politiques linguistiques éducatives en Europe, Conseil de l'Europe, Strasbourg, 2007.

${ }^{11}$ Ibid., p. 128.

12 Ibid., p. 126.

${ }^{13}$ Marisa Cavalli et al., L'éducation plurilingue et interculturelle comme projet, Conseil de l'Europe, 2009, http://www.coe.int/lang/fr (pristupljeno 9.9.2020.), p. 8.
} 
U maju 2019. godine Savet Evropske unije doneo je Preporuku o globalnom pristupu nastavi i učenju jezika, akt u kome se precizira da je neophodno da svaki građanin Evropske unije do kraja srednjoškolskog obrazovanja, pored maternjeg jezika, dostigne nivo jezičkih kompetencija na drugom evropskom jeziku na nivou koji mu omogućuje da efikasno koristi taj jezik u društvene i profesionalne svrhe kao i u svrhu učenja, a pored toga i da stekne znanje trećeg jezika na nivou koji bi $\mathrm{mu}$ omogućio da se tečno sporazumeva. Preporučuje se primena globalnih strategija u cilju poboljšanja nastave i učenja stranih jezika na nacionalnom, regionalnom, lokalnom ili školskom nivou. ${ }^{14}$

Istraživanje Eurobarometra iz 2006. pokazala su da građani Evrope razumeju značaj učenja stranih jezika. Prema podacima iz 2006. godine $84 \%$ ispitanika smatra da građanin Evropske unije treba da govori jedan strani jezik, a $50 \%$ smatra da treba da govori dva ili više stranih jezika. Međutim, kada je reč o praktičnoj primeni i efikasnom korišćenju stranih jezika podaci su zabrinjavajući. Eurobarometar iz 2012. pokazuje da samo 54\% stanovnika Evrope može da vodi konverzaciju na jednom stranom jeziku, oko $25 \%$ može da komunicira na dva strana jezika, dok samo $10 \%$ može da komunicira na tri strana jezika. ${ }^{15}$ Isto istraživanje pokazuje da samo $44 \%$ stanovnika Evrope može da razume jedan strani jezik u dovoljnoj meri da bi pratilo vesti na radiju ili televiziji. Dakle, nešto manje od polovine evropske populacije (46\%) ne govori dovoljno dobro nijedan strani jezik da bi mogao da ostvari konverzaciju na tom jeziku. Zanimljivo je i da, prema Eurobarometru iz 2012, oko dve trećine Evropljana (67\%) smatra da je engleski jedan od dva najkorisnija jezika za lični razvoj. Drugim rečima, iako je dugoročni cilj obrazovne jezičke politike EU da svaki građanin praktično koristi bar dva strana jezika, pored maternjeg, samo u osam zemalja članica je većina populacije u stanju da to i učini: u Luksemburgu (84\%), Holandiji (77\%), Sloveniji (67\%), Malti (59\%), Danskoj (58\%), Letoniji (54\%), Litvaniji (52\%) i Estoniji (52\%). U Luksemburgu je $61 \%$ ispitanika u stanju da govori tri strana jezika pored maternjeg. Države u kojima je najmanje ispitanika ocenilo da može aktivno da koristi bar dva jezika pored maternjeg su Portugal, Mađarska (13\%), Ujedinjeno Kraljevstvo (14\%) i Grčka (15\%).

Kada je reč o raspodeli jezika koji su zastupljeni u obrazovanju, lingvistička karta Evrope 2012. slična je onoj iz 2006. godine - najrasprostranjeniji je engleski jezik: 38\% ispitanika je učilo ili uči engleski kao strani jezik, slede francuski, $(12 \%)$, nemački (11\%), španski (7\%) i ruski (5\%). U odnosu na statistiku iz 2006.

\footnotetext{
14 "Council reccomendation of 22 May 2019 on a comprehensive approach to the teaching and learning of languages", Official journal of the European Union (2019/C 189/03) 5 june 2019, pp. 15-21.

15 "Special eurobarometer 385, Europeans and their languages" https://data.europa.eu/ euodp/en/data/dataset/S1049_77_1_EBS386 (pristupljeno 18.9.2020).
} 
primećuju se neznatne razlike od 2 do 3 procenta kada je reč o nemačkom i francuskom. Dominaciju engleskog potvrđuje i podatak da ga ispitanici navode kao jezik koji najtečnije govore, odnosno kao njihov prvi strani jezik (32\%).

Navedeni raskorak između deklarativne podrške evropskim idejama i njihove primene u praksi očigledan je i u Srbiji. Primena postulata evropske obrazovne politike temelji se na otvorenom modelu koordinacije koji predstavlja oblik saradnje u oblastima gde su nadležnosti i dalje u nacionalnom domenu, ali gde se namerava ojačati saradnja jer propisi naše zemlje nisu deo zajedničke pravne tekovine Evropske unije. ${ }^{16}$ Svakako su u poslednjih dvadeset godina učinjeni značajni pomaci u primeni evropske obrazovne jezičke politike u nastavi stranih jezika, u smislu usklađivanja programa nastave sa idejama iznetim u Zajedničkom evropskom referentnom okviru za jezike i primene evropskih postulata na unapređenje metodološkog pristupa u nastavi. Veliki napredak postignut je, pre svega, u primeni didaktičkog pristupa na kome Savet Evrope insistira tokom dugog niza godina, a koji je usmeren ka razvijanju efikasne komunikativne kompetencije kod učenika, koji obuhvata ne samo jezičke elemente nego i opšte kompetencije ličnosti, sociološku, kulturološku i afektivnu dimenziju komunikacije, kao i paralingvističke elemente u određenom specifičnom kontekstu u kome se govornik-korisnik jezika smatra društvenim akterom.

Međutim, kada je reč o zastupljenosti različitih jezika u obrazovnim sistemima, kao i o fondu časova opredeljenih za nastavu stranih jezika, analiza pokazuje da se u našem osnovnom i srednjem obrazovanju promovisanju postulata evropske obrazovne jezičke politike ne posvećuje dovoljna pažnja. Prema podacima iz 2013. godine, prvi strani jezik je u $95 \%$ slučajeva bio engleski, a ponuda stranih jezika u osnovnim i srednjim školama svodi se na samo nekoliko jezika: oko 80.000 učenika uči francuski jezik, 90.000 nemački, 62.000 ruski, 8.000 italijanski i 6.000 španski jezik, prema 600.000 učenika koji uče engleski jezik. ${ }^{17}$ Pored toga, nijedan regionalni ni manjinski jezik ne nudi se kao strani jezik. Sporan je i broj časova opredeljenih za nastavu prvog a naročito drugog stranog jezika koji nije dovoljan da bi učenici mogli, prema evropskim preporukama, da na kraju osnovne škole dostignu poznavanje prvog stranog jezika na nivou A2.2 i drugog stranog jezika na nivou A2.1 Evropskog zajedničkog referentnog okvira.

Nepovoljni položaj drugog stranog jezika u osnovnoškolskom i srednjoškolskom obrazovanju neumitno se odražava i na dalje školovanje i stručno

\footnotetext{
${ }^{16}$ Lidija Beko, Vera Ošmjanski, "Integrisana nastava (CLIL) na visokoškolskim institucijama i meko zakonodavstvo", Evropsko zakonodavstvo br. 60, Institut za međunarodnu politiku i privredu, Beograd, 2017, str. 310-319.

${ }^{17}$ Jelena Filipović, Julijana Vučo, “Serbian roadmap toward European plurilingualism”, Leonel Ruíz Miyares, María Rosa Álvarez Silva y Alex Muñoz Alvarado (eds.), Actualizaciones en comunicación social, vol. 1. Santiago de Cuba, Centro de Lingüística Aplicada, 2013, pp. 157-160.
} 
usavršavanje. Brojni autori ukazuju na nezainteresovanost nefiloloških fakulteta u Srbiji za strane jezike i nespremnost da ih uvrste u studijske programe. Oni navode da se strani jezici se na nefilološkim fakultetima smatraju opšteobrazovnim a ne stručnim predmetima, i sve češće se nude samo kao izborni predmeti, izjednačujući se sa veštinama. ${ }^{18}$ Pored toga, uprkos evropskim preporukama, jedino je engleski jezik zastupljen na većini fakulteta. Ova English only orijentacija jeste organizaciono lakša i globalno-politički uslovljena, ali ne i kulturno i obrazovno-akademski opravdana, i osiromašuje kako pojedinca tako i društvo te može imati dugoročne negativne posledice na obrazovni proces, nauku, ekonomiju, kulturu i uopšte na javni život zemlje. ${ }^{19}$ Pored smanjenja broja jezika koji se nude studentima na nematičnim fakultetima, poslednjih godina primetno je i smanjenje fonda časova stranog jezika struke. ${ }^{20}$

Kada je reč o univerzitetima, takođe smo svedoci sve nepovoljnijeg položaja stranog jezika struke, kao i negativnog efekta nepoznavanja različitih stranih jezika na pristup stranoj stručnoj literaturi i programima mobilnosti studenata. Nepoznavanje drugog stranog jezika izuzev engleskog sužava mogućnost korišćenja stručne literature i sagledavanje naučnih domena iz različitih izvora, na različitim jezicima i sa različitih aspekata. Uprkos postojanju mnogobrojnih programa mobilnosti i sve većoj ponudi razmene studenata od strane evropskih zemlja koje nisu anglofone, veliki broj studenata nije u mogućnosti da aplicira za ove programe jer osim engleskog ne govori nijedan drugi strani jezik.

Koji su razlozi ovakvog raskoraka između šezdesetogodišnjeg zalaganja evropskih institucija za kreiranje obrazovnih jezičkih politika koje će favorizovati plurilingvizam i jezičku raznovrsnost i nedovoljne primene ovih koncepata u praksi? Mnogi autori smatraju da je veliki problem u tome što se u obrazovnim sistemima svih evropskih zemalja favorizuju takozvani veliki jezici. Tov Skutnab-Kangas ocenjuje da evropski akti samo na prvi pogled insistiraju na jezičkoj ravnopravnosti i valorizaciji plurilingvizma i da se smernice Saveta Evrope i institucija Evropske unije ne sprovode u praksi, nego da se naprotiv koncept očuvanja malih jezika u stvari koristi kako bi se ojačala nadmoć dominantnih jezika. ${ }^{21}$ Drugi autori smatraju

\footnotetext{
${ }^{18}$ Ana Vujović, „Položaj francuskoj jezika na nefilološkim fakultetima u Srbiji”, Cakeljić V., Vujović A., Stevanović M. (ur.), III Međunarodna konferencija Strani jezik struke: prošlost, sadašnjost, budućnost, zbornik radova, Beograd, Fakultet organizacionih nauka, 2014, str. 583.

${ }^{19}$ Julijana Vučo, „Internacionalizacija univerziteta i jezičke potrebe”, Vujović A., Šipragić D., Đokić, S., Paprić M. (ur.) Strani jezik struke i profesionalni identitet - IV međunarodna konferencija, zbornik radova, Beograd, Društvo za strane jezike i književnost Srbije, 2018, str.75.

${ }^{20}$ Anđelka Ignjačević, “Reality of LSP teaching in Serbia”, Ignjačević, A., Đorović, D., Janković N., Belanov M., (ur.) Jezik struke - Izazovi i perspektive, Univerzitet u Beogradu, 2011, str. 941.

${ }^{21}$ Tove Skutnabb-Kangas, Why Should Linguistic Diversity Be Maintained And Supported In Europe? Some Arguments, Council of Europe, Language Policy Division, Strasbourg, 2002.
} 
da je problem u neobavezujućem i nepreskriptivnom karakteru akata u kojima je zacrtana ova politika, budući da je najčešće reč o preporukama, deklaracijama ili smernicama, kao i nepreciznost jezičkih formulacija koje se u aktima koriste kada se propisuju mere koje države treba da preduzmu („kad god to okolnosti dozvoljavaju” "ukoliko je to moguće” „odgovarajuće” mere „imajući u vidu okvire, ograničenja i prioritete njihovih političkih, pravnih, budžetskih i obrazovnih sistema" itd.). ${ }^{22}$ Može se reći i da međunarodne organizacije zapravo stvaraju i promovišu globalni obrazovni diskurs nudeći univerzalni model obrazovanja kao globalnu strategiju za rešavanje većine problema u veoma različitim obrazovnim kontekstima. Globalni akteri (pre svega, međunarodne organizacije) imaju vrlo sličan pogled na to kako treba da izgleda obrazovanje u informatičkom dobu, te često promovišu vrlo slične principe obrazovanja i razvoja uopšte, koji treba da budu prihvaćeni u većini zemalja. ${ }^{23}$ Pojedini autori ističu da je ova situacija posledica primene principa supsidijariteta, prema kome Evropska unija ne preduzima radnje (izuzev u oblastima svojih isključivih nadležnosti), osim ako one nisu delotvornije od radnji preduzetih na nivou države članice, regije ili lokalne samouprave. ${ }^{24,25}$ Konačno, pošto se principom supsidijariteta omogućuje svakoj državi da ima svoju obrazovnu jezičku politiku, možemo se zapitati postoji li uopšte zajednička evropska obrazovna jezička politika ili treba govoriti o obrazovnim politikama država EU.

Istraživanja sprovedena sa studentima Pravnog fakulteta Univerziteta $u$ Beogradu pokazala su da je većina studenata zainteresovana za programe mobilnosti, ali da veliki broj ocenjuje da njihovo znanje francuskog, nemačkog, španskog, ili drugog stranog jezika koji nije engleski, nije na zadovoljavajućem nivou i da se zbog toga do sada nisu prijavljivali za te programe. U prvom istraživanju sprovedenom $2017 / 2018$. godine ispitivana su stanovišta studenata prema učenju stranih jezika uopšte, a posebno prema poznavanju stranog jezika struke: koliko poznavanje stranog jezika utiče na konkurentnost na tržištu rada i pronalaženje zaposlenja u pravnoj struci. Podaci prikupljeni pomoću upitnika pokazali su da studenti smatraju da jezičke kompetencije imaju veliki uticaj na zapošljivost: 76\%

${ }^{22}$ Katarina Radojković Ilić, „Postulati evropske obrazovne jezičke politike i nastava stranih jezika”, Evropsko zakonodavstvo br. 64, Institut za međunarodnu politiku i privredu, Beograd, 2018, str. 220.

${ }^{23}$ Vera Spasenović, Obrazovna politika: globalni i lokalni procesi, Institut za pedagogiju i andragogiju Filozofskog fakulteta, Beograd, 2019.

${ }^{24}$ Zoltan Tozser, "The European Union's Language Policy”, Debrecen 2013, Thesis, https:// www.academia.edu/6088868/2013_ZOLTAN_TOZSER_The_European_Unions_Language_Policy (pristupljeno 15.9.2020), p. 10.

${ }^{25}$ Elise Ahn, "A Region Divided/United: Language Policy Developments in the European Union", Conference paper prepared for the European Union Studies Association 2007 Biennial Conference (Montreal, Canada) http://aei.pitt.edu/7679/1/ahn-e-05h.pdf, p. 12. 
studenata smatra da poznavanje stranih jezika veoma utiče na zapošljivost, $24 \%$ da prilično utiče, nijedan od ispitanika ne smatra da poznavanje jezika nema uticaja na zapošljivost. Pored toga, prilikom rangiranja kompetencija koje mogu uticati na zapošljivost, ispitanici su jezičkim kompetencijama dali skoro jednak značaj kao i stručnim znanjima. ${ }^{26}$ Drugo istraživanje sprovedeno je tokom 2019/2020. godine sa studentima druge, treće i četvrte godine koji su kao strani jezik struke odabrali francuski jezik, ali se istraživanje nije ograničilo na upotrebu ovog jezika već na upotrebu bilo kog stranog jezika. ${ }^{27}$ Korišćena je metoda upitnika koji se sastojao od 12 pitanja sa višestrukim izborom i dva otvorena pitanja. Rezultati pokazuju da je većina studenata do tada učila dva (93/110) ili tri strana jezika (17/110). Ispitanici su naveli da su u većini učili strani jezik od prvog, odnosno petog razreda osnovne škole i da su u većini učili engleski kao prvi strani jezik. Studenti koji su naveli da su učili više stranih jezika pored engleskog i francuskog učili su nemački (6 studenata), španski (2), ruski (6), italijanski (2) i mađarski (1), i napomenuli su da su treći jezik učili na tečajevima u privatnim školama. Kada je reč o značaju koji pridaju upotrebi jezika u profesionalne svrhe i u svakodnevnom životu rezultati su pokazali da studenti pridaju izuzetno veliki značaj poznavanju stranih jezika u oba konteksta $-83 \%$ studenata smatra da je poznavanje stranih jezika veoma važno za svakodnevni život, $17 \%$ da je važno, nijedan student nije ocenio da je znanje jezika nevažno. Slični su odgovori kada je reč o profesionalnom kontekstu $(81 \%$ je zaokružilo odgovor „veoma važno”, 19\% „važno”, nijedan odgovor „nevažno”). Na pitanje u kojim situacijama koriste strani jezik van studija ispitanici su kao najčešće naveli gledanje filmova i televizije i slušanje muzike, zatim pretraživanje interneta, putovanja i komunikaciju sa strancima (kolegama, prijateljima, rođacima). Nijedan student nije zaokružio odgovor da uopšte ne koristi strani jezik u svakodnevnom životu (slika 1) . Kada je reč o situacijama u oblasti studija u kojima koriste strani jezik, studenti navode da ga najčešće koriste za čitanje stručne literature i izradu seminarskih radova, i učešće u različitim međunarodnim aktivnostima kao što su različita studentska takmičenja.

Rezultati su jasno pokazali i da je većina studenata zainteresovana za programe mobilnosti (98\% ispitanika), ali da veliki broj ocenjuje da njihovo znanje stranog jezika nije na zadovoljavajućem nivou i da se zbog toga do sada nisu prijavljivali za te programe (88\%). Budući da prema podacima kojima raspolaže administracija, godišnje u proseku pet studenata Pravnog fakulteta realizuje mobilnost na nekom

\footnotetext{
${ }^{26}$ Detaljnije o ovom istraživanju u: Katarina Radojković Ilić, „Uticaj poznavanja stranih jezika na socijalnu koheziju u Srbiji”, Vladimir Ilić (ur.), Socijalna politika na raskršću vekova, Visoka škola socijalnog rada, Крымский федеральный университет имени В.И. Вернадского, Beograd 2019, str. 311-324.

${ }^{27}$ Istraživanje je sprovedeno u okviru projekta Identitetski preobražaj Srbije 2020, čiji je nosilac Pravni fakultet Univerziteta u Beogradu.
} 
od frankofonih univerziteta u okviru programa Erasmus+, i za koje se u većini slučajeva traži poznavanje francuskog jezika na nivou B1 ili B2, studenti su zamoljeni da ocene svoje jezičke kompetencije u odnosu na te nivoe. Odgovori su pokazali većina ocenjuje svoje jezičke kompetencije kao nedovoljne da bi pratila predavanja na stranom jeziku, komunicirala sa kolegama ili koristila strane udžbenike. Studenti takođe u većini smatraju da je jedan semestar nedovoljan za učenje pravnog jezika struke (98\%) i ocenjuju da bi strani jezik struke trebalo da se uvede i na drugim godinama studija.

Slika 1: Prikaz situacija u kojima ispitanici najčešće koriste strane jezike.

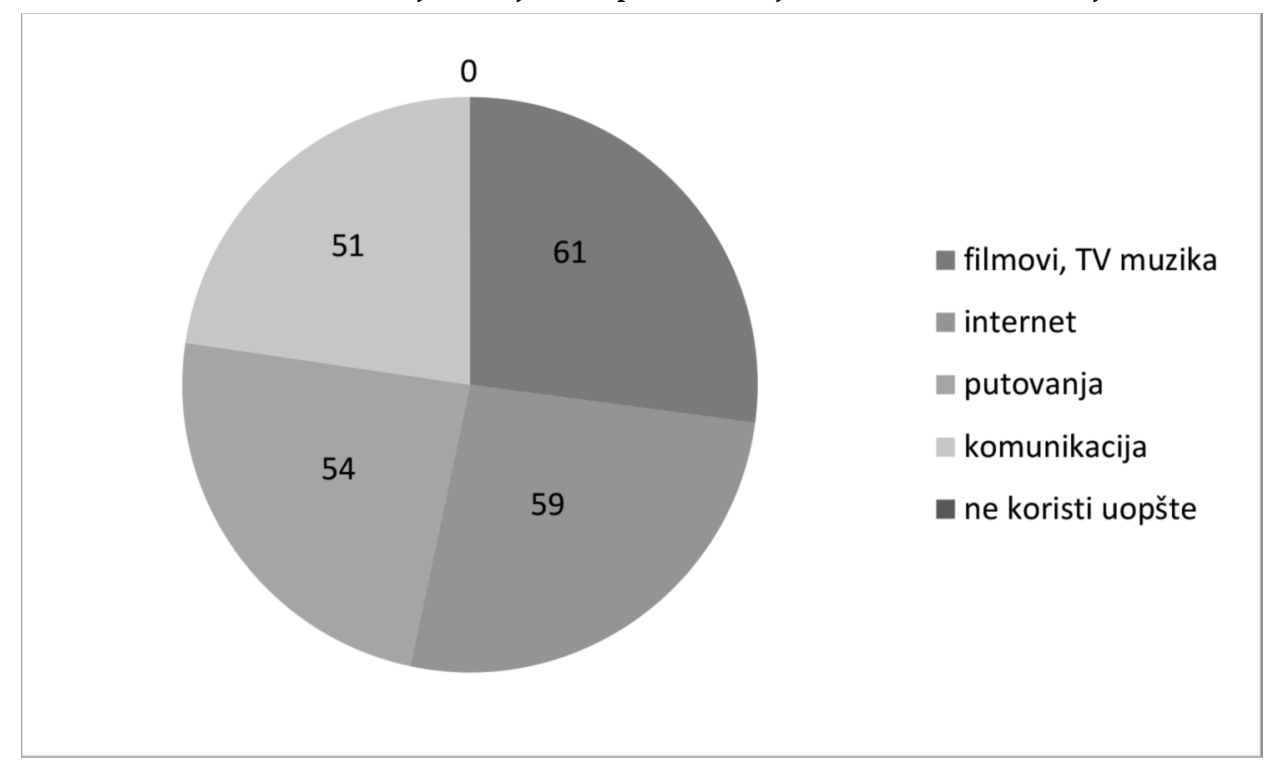

Studenti su veoma svesni značaja učenja stranih jezika te je većina ispitanika (85\%), iako je ocenila svoje znanje jezika nedovoljnim da bi ga koristila za programe mobilnosti ili studiranje u inostranstvu, izjavila da namerava da u budućnosti poboljša svoje jezičke sposobnosti (slika 2). 
Slika 2: Samoprocena jezičkih kompetencija potrebnih za učešće u programima mobilnosti.

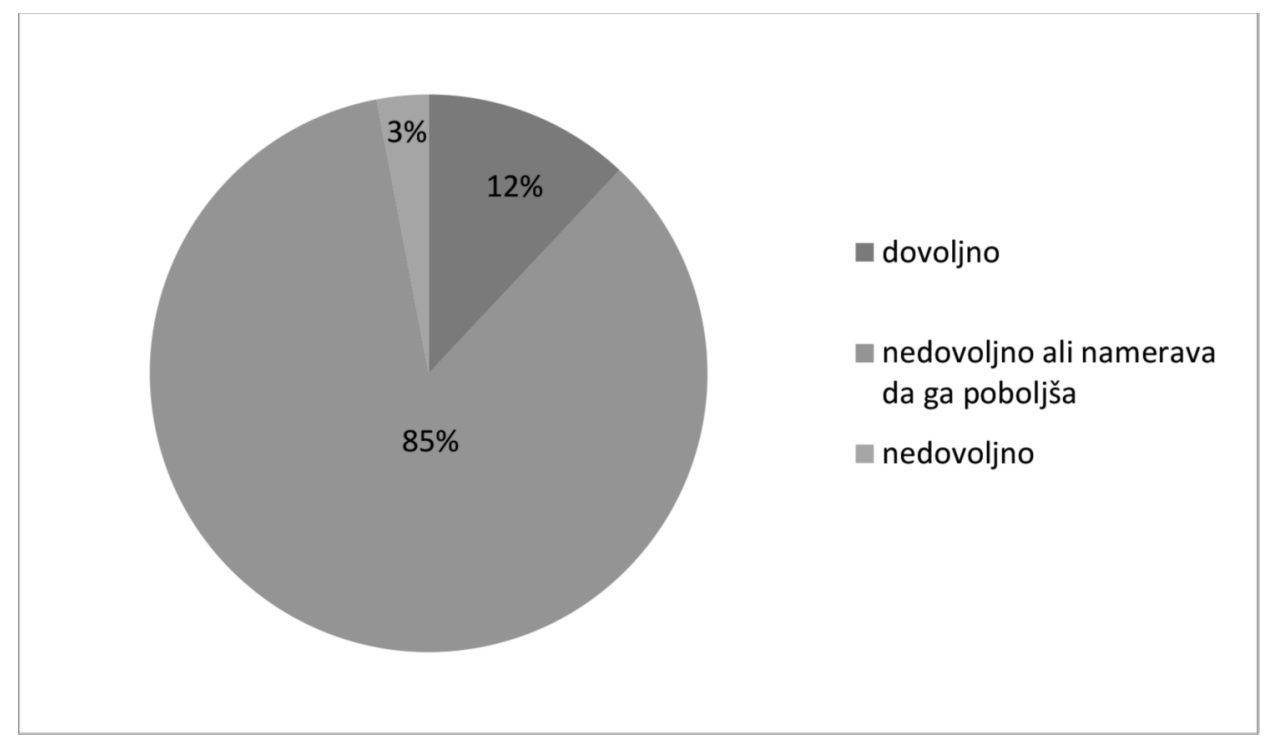

\section{3) ZAKLJUČAK}

Oba istraživanja pokazuju da su studenti izuzetno svesni značaja poznavanja stranih jezika kako u privatnom tako i u profesionalnom kontekstu. Posebno je zanimljivo da su ispitanici jezičkim kompetencijama dali skoro jednak značaj kao i stručnim znanjima kada je reč o mogućnosti pronalaženja posla u pravnoj struci. Takođe je zanimljivo da studenti ocenjuju da jednosemestralna nastava stranog jezika struke nije adekvatna njihovim potrebama za komunikaciju u profesionalnom okruženju, niti za čitanje stručne literature. Zanimljiv je i podatak da u oba sprovedena istraživanja nijedan ispitanik nije izjavio da uopšte ne koristi strani jezik van studija. Zabrinjavajući su, međutim, podaci koji ukazuju da je veliki broj studenata zainteresovan za programe mobilnosti, ali da veliki broj ocenjuje da njihovo znanje jezika nije na zadovoljavajućem nivou i da se zbog toga nisu prijavili za te programe. Utešno je, ipak, da velika većina ispitanika namerava da poboljša svoje znanje jezika izvan formalnog obrazovanja da bi mogli u budućnosti da se prijavljuju za programe kao što je Erasmus, da apliciraju za inostrane stipendije ili nastave dalje školovanje i stručno usavršavanje na stranom jeziku. U svetlu te činjenice moramo da se zapitamo - da li naš obrazovni sistem pruža jednake šanse svima, ili plurilingvizam i dalje ostaje privilegija bogatijih slojeva društva i intelektualne elite? Ovo istraživanje pokazalo je, kao i mnoga pre njega, da su mladi 
ljudi svesni značaja komunikacije na stranim jezicima i ukazuje na potrebu da se formalno obrazovanje rukovodi preporukama kako obrazovne jezičke politike EU, tako i stručne javnosti. Takođe, ukazuje da je neophodno da kreatori obrazovne jezičke politike prihvate da je plurilingvizam realnost, i da u modernom društvu postoji potreba svakog pojedinca za poznavanjem i korišćenjem više jezika, na različitim nivoima u poslovnom i privatnom okruženju.

\section{4) LITERATURA}

Ahn, Elise, "A Region Divided/United: Language Policy Developments in the European Union", Conference paper prepared for the European Union Studies Association 2007 Biennial Conference (Montreal, Canada).

Beacco, Jean-Claude, Byram, Michel, De la diversité linguistique à l'éducation plurilingue - Guide pour l'élaboration des politiques linguistiques éducatives en Europe, Conseil de l'Europe, Strasbourg, 2007.

Beko, Lidija, Ošmjanski, Vera, „Integrisana nastava (CLIL) na visokoškolskim institucijama i meko zakonodavstvo", Evropsko zakonodavstvo br. 60, Institut za međunarodnu politiku i privredu, Beograd, 2017, str. 310-319.

Cavalli, Marisa, Coste, Daniel, Crisan, Alexandru, Van de Ven, Piet-Hein, L'éducation plurilingue et interculturelle comme projet, Conseil de l'Europe, Strasbourg, 2009.

Filipović, Jelena \& Vučo, Julijana, "Serbian roadmap toward European plurilingualism", Leonel Ruíz Miyares, María Rosa Álvarez Silva y Alex Muñoz Alvarado (eds.) Actualizaciones en comunicación social, vol. 1. Santiago de Cuba, Centro de Lingüística Aplicada, 2013. str.157-160.

Ignjačević, Anđelka, "Reality of LSP teaching in Serbia", Ignjačević, A., Đorović, D., Janković, N., Belanov, M. (ur.), Jezik struke - izazovi i perspektive, Univerzitet u Beogradu, 2011, str. 938-942.

Radojković Ilić, Katarina, „Postulati evropske obrazovne jezičke politike i nastava stranih jezika", Evropsko zakonodavstvo br. 64/2018, Institut za međunarodnu politiku i privredu, Beograd, 2018, 207-223.

Radojković Ilić, Katarina, „Uticaj poznavanja stranih jezika na socijalnu koheziju u Srbiji", Vladimir Ilić (ur.) Socijalna politika na raskršću vekova, Visoka škola socijalnog rada, Крымский федеральный университет имени В.И.Вернадского, Beograd 2019, str. 311-324.

Skutnabb-Kangas, Tove, Why Should Linguistic Diversity Be Maintained And Supported In Europe? Some Arguments, Council of Europe, Language Policy Division, Strasbourg, 2002.

Spasenović, Vera, Obrazovna politika: globalni i lokalni procesi, Institut za pedagogiju i andragogiju Filozofskog fakulteta, Beograd, 2019. 
Tozser, Zoltan, The European Union's Language Policy, University of Debrecen, Faculty of Arts, Institute of English and American Studies, 2013.

Vučo, Julijana, „Internacionalizacija univerziteta i jezičke potrebe”, Vujović, A., Šipragić Đokić, S, Paprić, M. (ur.), Strani jezik struke i profesionalni identitet - IV međunarodna konferencija, zbornik radova, Društvo za strane jezike i književnost Srbije, Beograd, 2018, str. 69-83.

Vujović, Ana, „Položaj francuskog jezika na nefilološkim fakultetima u Srbiji”, Cakeljić. V., Vujović, A., Stevanović, M. (ur ), III Međunarodna konferencija Strani jezik struke: prošlost, sadašnjost, budućnost, zbornik radova, Fakultet organizacionih nauka, Beograd, 2014, str. 581-588.

\section{PLURILINGUALISM AND THE EU LANGUAGE EDUCATION POLICY IN SERBIA}

Summary: The paper discusses plurilingualism as one of the main objectives of European language ideology, plurilingual and intercultural education whose main goal is to promote humanistic values, mutual respect, tolerance and dialogue between nations. The paper cites some of the acts of the Council of Europe and the institutions of the European Union in which plurilingualism and the preservation of the language of diversity are emphasized as the most important goals of the EU language education policy. It also discusses some of the controversial issues related to language education in the countries of the European Union and analyzes the presence of those concepts in the language education policy in the Republic of Serbia. The paper also presents the results of research conducted with the students of the Faculty of Law of the University of Belgrade. It offers insights into the students' experience and their attitudes towards the importance and the impact of language knowledge and access to student mobility programs.

Keywords: EU language education policy, Council of Europe, European Union, plurilingualism, foreign language teaching. 